\title{
Submarine Landslide Source Modeling using the 3D Slope Stability Analysis Method for the 2018 Palu-Sulawesi Tsunami
}

Chatuphorn Somphong ${ }^{1}$, Anawat Suppasri ${ }^{1}$, Kwanchai Pakoksung ${ }^{1}$, Tsuyoshi Nagasawa ${ }^{2}$, Yuya Narita $^{2}$, Ryunosuke Tawatari ${ }^{2}$, Shohei Iwai ${ }^{2}$, Yukio Mabuchi ${ }^{2}$, Saneiki Fujita ${ }^{1}$, Shuji Moriguchi ${ }^{1}$, Kenjiro Terada ${ }^{1}$, 5 Cipta Athanasius ${ }^{3}$ and Fumihiko Imamura ${ }^{1}$

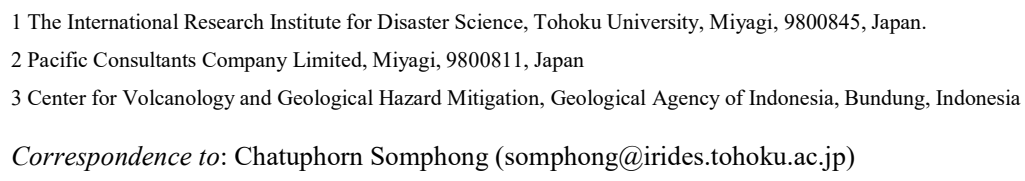

10 Abstract. Studies have indicated that submarine landslides played an important role in the 2018 Sulawesi tsunami event, damaging the coast of Palu Bay in addition to the earthquake source. Most of these studies relied on visible landslides to reproduce tsunamis but could still not fully explain the observational data. Recently, several numerical models included hypothesized submarine landslides that were taken into account to obtain a better explanation of the event. In this study, for the first time, submarine landslides were simulated by applying a numerical model based on Hovland's 3D slope stability analysis

15 for cohesion-frictional soils. To specify landslide volume and location, the model assumed an elliptical slip surface on a vertical slope of $27 \mathrm{~m}$ of mesh-divided terrain and evaluated the minimum safety factor in each mesh area based on the surveyed soil property data extracted from the literature. The landslide output was then substituted into a two-layer numerical model based on a shallow-water equation to simulate tsunami propagation. The results were combined with the other tsunami sources, i.e., earthquakes and observed coastal collapses, and validated with various postevent field observational data, including tsunami

20 runup heights and flow depths around the bay, the inundation area around Palu city, waveforms recorded by the Pantoloan tide gauge, and video-inferred waveforms. The model generated several submarine landslides, with lengths of 0.2-2.0 km throughout Palu Bay. The results confirmed the existence of submarine landslide sources in the southern part of the bay and showed agreement with the observed tsunami data, including runups and flow depths. Furthermore, the simulated landslides also reproduced the video-inferred waveforms in 3 out of 6 locations. Although these calculated submarine landslides still cannot

25 fully explain some of the observed tsunami data, they emphasize the possible submarine landslide locations in southern Palu Bay that should be studied and surveyed in the future.

\section{Introduction}

Indonesia has recently experienced hardship because of earthquakes and tsunamis. Approximately 2.5 million people have been exposed to a tsunami with a 500 year return period, and a recent study suggested that Indonesia ranks third in the world for the

30 proportion of the population exposed to tsunamis (Løvholt et al., 2014). A total of 9 tsunamis have been observed since 2000, 8 of which were associated with a significant earthquake, including the deadly Indian Ocean tsunami in 2004, according to the National Geophysical Data Center/World Data Service (NGDC/WDS, 2021). These types of natural disasters have caused many economic losses and fatalities in Indonesia. The country experienced limitations in reconstruction after the 2004 tsunami (Suppasri et al., 2015). Horspool et al. (2014) indicated that the annual probability of experiencing a tsunami similar to the 35 aforementioned $3.0 \mathrm{~m}$ tsunami is $\sim 0.1-10 \%$ across the entire Indonesian coast. 
The $\mathrm{M}_{\mathrm{w}} 7.5$ earthquake that occurred on September 28, 2018, near Central Sulawesi, Indonesia (Lat.: $0.256^{\circ} \mathrm{S}$, Long.: $119.846^{\circ} \mathrm{E}$ ), was caused by strike-slip faulting at shallow depths within the interior of the Molucca Sea microplate, which is part of the broader Sunda tectonic plate (USGS, 2018). The ruptured fault is a segment of a major active strike-slip fault zone named the Palu-Koro Fault System (Liu et al., 2020). A major surface rupture with a $4 \mathrm{~m}$ maximum left-lateral offset was identified 40 during a field survey in the NW Palu Valley (Patrai et al., 2020). In addition, a $5.8 \mathrm{~m}$ surface rupture in Pawunu village occurred approximately $15 \mathrm{~km}$ south of Palu city (Banda Geologi, 2018). A unanticipated tsunami was triggered by this earthquake and caused damage around Palu Bay. The cumulative impacts from this tsunami led to approximately 2,100 fatalities and more than 68,000 damaged houses (Pang, 2018; Hadi and Kurniawati, 2018). Several post-earthquake-tsunami field surveys reported damage along the Palu Bay coast and indicated runup heights above $6.0 \mathrm{~m}$ (Mikami et al., 2019), specifically $\sim 9.1 \mathrm{~m}$ runup 45 heights and $8.7 \mathrm{~m}$ inundation depths at Benen village (Omira et al., 2019) and $\sim 10.7 \mathrm{~m}$ runup heights in Tondo (Widiyanto et al., 2019). Outside of the bay, there is little evidence of tsunami flooding-related disruption, implying that most tsunamigenic sources were located within the bay (Liu et al., 2020)

\subsection{Review of the attempts to model tsunami sources}

Many attempts have been made to reproduce Palu tsunami events through modeling; however, these studies produced different

50 outputs based on various tsunami sources. The finite fault model proposed by the USGS created only small vertical ground displacements that were not large enough to cause significant tsunamis within the bay (Pakoksung et al., 2019). Augmentations to the sources of the tsunami have been made. Due to the difficulty in reproducing the observed tsunami runup heights and the Pantoloan tide gauge record, landslide sources have been proposed as an additional source. At the Pantoloan tide gauge station in Palu Bay, time series of a tsunami waveform was recorded. Several videos of the tsunami's arrival were also captured. Carvajal

55 et al. (2019) used these videos to calculate the tsunami's arrival times and infer the waveforms at each site and emphasized that coastal/submarine landslides were main contributing sources of this Palu tsunami.

Simulations of earthquake-generated tsunamis and submarine landslide-generated tsunamis involve different approaches. The generation of a tsunami induced by submarine landslides is a complicated process. Coupled dynamic models for earthquakegenerated tsunamis have been well established and are commonly used, while coupled dynamic models for landslide-generated

60 tsunamis are still limited (Heinrich et al., 2001; Pakoksung et al., 2019). Various modeling efforts have been carried out to simulate tsunami propagation using the COMCOT model (Heidarzadeh et al. 2019; Carvajal et al., 2019; Gusman et al. 2019; Liu et al., 2020; Sepúlveda et al., 2020). In more recent works, several studies have been performed to simulate landslideinduced tsunamis using other uncoupled methods, in which the landslide mass and tsunami propagation are separately calculated (Nakata et al., 2020, Paris et al., 2020; Ulrich et al. 2019; Schambach et al., 2021).

65 Some previous works have successfully acquired agreeable results by comparing the surveyed runup heights to the inundation depths, the recorded water levels at the Pantoloan tide gauge, or video-inferred waveforms. Many previous studies have used numerical models to reproduce a waveform at the Pantoloan tide gauge and have obtained good agreement with recorded data (e.g., Heidarzadeh et al. 2019; Carvajal, M. et al., 2019; Takagi et al., 2019; Jamelot et al., 2019). Additionally, several studies have attempted to model the tsunami runup heights and inundation depths, have compared them to the surveyed data, and have

70 achieved accepTable comparisons (e.g., Pakoksung et al. 2019; Ulrich et al. 2019). Moreover, some studies have focused on inundation in Palu city. For example, Gusman et al. (2019) performed a simulation using vertical displacement and landslide sources to determine the inundation depths and area and compared the results with high-resolution field measurements by Paulik et al. (2019). More updated studies have attempted to reproduce video footage-based waveforms, as proposed by Carvajal, M. et al. (2019). In some works, hypothesized landslide sources are required to explain video-inferred waveforms (e.g., Nakata et al., 
75 2020; Schambach et al., 2021). Moreover, combining seismic fault slip with observed landslide sources can also explain the wave characteristics based on video footage. For instance, Sepúlveda et al., 2020 combined landslide sources with coseismic ground displacement measured by Interferometric Synthetic Aperture Radar (InSAR) with different fault geometry configurations and archived the simulated tsunamis that were consistent with all of the tsunami data, including surveyed runup heights and video-inferred waveforms. These studies conducted simulations with different numerical models that used different

80 sources of tsunamis or sources of landslide data to explain certain types of observational data. Table 1 summarizes the past literature with respect to numerical models, tsunami sources, landslide data sources and verification data.

\subsection{Review of submarine landslides in Palu Bay}

Several studies have observed visible coastal landslides or submarine landslides through various methods. Small submarine landslide sources were identified from eyewitness accounts and field surveys (Arikawa et al. 2018). Sassa and Takagawa (2018)

85 suggested that liquefaction induced coastal land collapse, which resulted in liquefied sediment flows and eventually led to a tsunami. Carvajal et al. (2019) used video footage and satellite images to identify visible coastal land collapses, and these landslide sources were used by later studies, including Gusman et al. (2019) and Tegaki et al. (2019). Liu et al. (2020) studied coastal landslides by comparing pre-earthquake bathymetry to their surveyed postearthquake bathymetry. These observed landslide locations are mapped and summarized in Fig. 1. Since actual submarine landslides are difficult to detect, hypothesized

90 landslides have been proposed as an alternative in more recent works. Pakoksung et al. (2019) introduced four mega-sized landslides with volumes of $\sim 10-38$ million $\mathrm{m}^{3}$ : three in the upper outside of Palu Bay and one in the lower part. Similarly, Nakata et al.’s (2020) study strongly emphasized a potential submarine landslide in the nearshore area near Palu city (Fig. 1).

\subsection{Research objectives}

Earthquake-induced tsunami modeling in previous studies cannot fully explain observational data. A better model for 95 reproducing these tsunami impacts may be to reproduce tsunami events. Many past studies rely on hypothesized submarine landslides (Takagi et al., 2019; Pakoksung et al., 2019; Nakata et al., 2020) and suggest various potential submarine landslides within Palu Bay. This raises the question of whether exact landslides could actually occur in these areas and requires further investigation regarding these undiscovered submarine landslides. Therefore, more studies should focus on modeling submarine landslide sources.

100 To the best of our knowledge, no existing studies have considered modeling submarine landslide sources based on slope stability analysis and the available observed soil data. The objectives of this study are to

1) present probable submarine landslide sources using a sophisticated landslide model based on 3D slope stability analysis (which has never been performed according to the existing literature) that reflects the existing observational soil data, and then check whether the simulated submarine landslides match the observations or are located within potential areas suggested by past studies.

2) reproduce all the field observations of tsunami records, including the runup height, flow depth (or inundation depth) around Palu Bay, Pantoloan tide gauge waveform, video-inferred waveforms, and inundation depths and area in Palu city, with the developed landslide model. 


\section{Methodology}

110 This section is composed of three parts. First, the landslide model is introduced; second, the numerical model used for tsunami propagation is introduced. Last, the data used for model settings and observational data used for model verifications are presented.

Figure 2 presents the workflow of this study regarding modeling procedures. Generally, there are 2 models: landslide and tsunami models. The former model considers the significant measured soil parameters as an input, including unit weight,

115 cohesion, and internal friction angle. The modeling requires the initial water level and groundwater conditions according to the bathymetry. Similar to Nakata et al. (2020) and Paris et al. (2020), the landslide model assumes the initial shape of the landslide mass to be an ellipsoid. The geometry of landslides includes the maxima of the major and minor radii of the ellipsoid and the soil layer thickness. The seismic force is considered an additional sliding force in this study, which is discussed in a later section. Once the parameters are set, the model calculates the landslide mass (or landslide thickness) and the location of the landslide

120 based on the minimum safety factor; these values are input into the tsunami model. The second part of the modeling procedure simulates tsunami propagation. This study adopts the same methodology as Pakoksung et al. (2019), details of which are explained in a later section. The reproductions of tsunami runup height, inundation depth, Pantoloan tide gauge waveform, video-inferred waveforms at 6 locations, and inundation area in Palu city are determined to validate the observational data. The Comparison Index (Aida, 1978) is used to quantitatively compare the measured and calculated runup heights and inundation

125 depths. The input soil parameters and landslide geometry are repeatedly calibrated and adjusted until the Comparison Index reaches agreeable values.

\subsection{Landslide model}

\subsubsection{Model description}

This study adopts a model based on Hovland's (1977) method as the landslide model. In Hovland's method, the collapsed soil

130 mass cut off by the slip surface is decomposed into square or rectangular soil columns. Hovland's method defines the threedimensional factor of safety as the ratio of the total available resistance along the failure surface to the total mobilized stress along it (Ahmed et al., 2012). The safety factor formula for Hovland's method is shown in Eq.1:

$F=\frac{\sum_{x} \sum_{y}[c A+\gamma \Delta x \Delta y \cos (D I P) \tan \emptyset]}{\sum_{x} \sum_{y} \gamma z \Delta x \Delta y \sin \alpha_{y z}}$

where $F$ is the safety factor, $c$ is the adhesive strength, $\phi$ is the internal friction angle, $A$ is the area of the slip surface, $\Delta x$ and $\Delta y$

135 are the soil mass length and width when the column is projected onto the $x y$ plane, $\alpha_{y z}$ is the angle formed by the slip plane and the $y z$ plane, $D I P$ is the inclination direction of the slip surface, $z$ is the depth of the soil mass, and $\gamma$ is the unit weight of the soil mass. From the above, the formula can be simplified as the proportion of the resistance of the entire slipping soil mass, $Q=\Sigma Q_{i}$, over the sliding force, $S=\Sigma S_{i}$, as Eq. 2 :

$F=\frac{\sum Q_{i}}{\sum s_{i}}$

140 For stability over seismic activity, the design horizontal seismic intensity is introduced to consider the influence of the earthquake. The horizontal force due to the earthquake motion is assumed to be a part of the weight of the soil mass in the horizontal direction, as shown in Fig. 3a. The design horizontal seismic intensity is given as a vector $k$ in the same horizontal direction as the gradient direction of the calculated element for each soil column. At this time, the resistance force $\left(Q_{i}\right)$ and sliding force $\left(S_{i}\right)$ of each soil mass are described as follows.

$145 Q_{i}=\left[c A_{i}+\left\{n_{i} \cdot\left(e_{g}+k\right)\left(t_{i} \cdot u_{i}\right)\left(W-W_{i}\right)\right\} \cdot \tan \phi\right] u_{i}$ 
where $A_{i}$ is the area of the sliding surface, $W_{i}$ is the weight of the earth column, and $n_{i}$ and $t_{i}$ are the unit vectors perpendicular to and parallel to the sliding surface, respectively. $u_{i}$ is the direction in which the slip body slides and is determined at the same time as the slide body. $e_{g}$ is the unit vector in the direction of gravity (Fig. 3b).

150 Generally, the input soil parameters that are typically required for numerical modeling are soil unit weight, tensile strength, Young's modulus, Poisson's ratio, cohesion and angle of friction (Kumar et al., 2016). In this study, the landslide model requires 3 essential soil parameters: the saturated condition of the cohesion, the internal friction angle and the unit weight of the soil. In this study, landslide failure was analyzed by considering a safety factor $<1$.

\subsubsection{Measured soil data and landslide model settings}

155 Observations of the submarine soil properties in Palu Bay do not exist in the literature. This research adapts soil data from field observations near the bay. The soil properties are defined by the pressure- and shear-wave velocity $\left(V_{p}\right.$ and $\left.V_{s}\right)$ profiles inferred from horizontal-to-vertical spectral ratio (HVSR) microtremor inversion over the soil depth, which was proposed by Cipta et al. (2020). Subsequently, $V_{s}$ is translated to the standard penetration test (SPT) count $(N)$ by the empirical equation proposed by Kirar et al. (2016) for all soil types: $V_{s}=99.5 N^{0.345}$. Overall, based on the measured soil properties, the study area is categorized

160 into 3 main parts: upper, middle and lower Palu Bay, as shown in Fig. 4. By the mechanism in the landslide model, the soil layers are categorized into 2 main layers: the sliding layer(s) and base layer. Land failure is allowed on only the sliding layers (as shown by the stratum in Fig. 5). This research considers only 2 stratums based on the observed soil properties in Fig. 4 and applies those from observation sites 504, 402 and 1001 for strata in the Upper Bay, Middle Bay and Lower Bay, respectively. In addition, the soil properties are assumed to be saturated soil conditions, which significantly affect the result more than dry soil

165 conditions in the landslide model.

After determining the SPT $N$ value, the saturated soil cohesion and internal friction angle are calculated from the empirical equations proposed by Kumar et al. (2016). The cohesion (C) can be computed from $C=-2.2049+6.484 N$, for $N$ ranges from 230 (for $\mathrm{N}<2$, we assume a random low $C$ value). Moreover, the angle of internal friction $(\varphi)$ is calculated from $\varphi=7 N$ for $N<$ 4. $\varphi=27.12+0.2857 N$ when $N$ is in the range of 4-50. The values of these soil properties are tested to find good agreement with

170 the observed tsunami runup height and inundation depth and can be slightly different from the actual computed values from the above equations. Groundwater is assumed to exist, and the groundwater level is equal to the seabed elevation for all areas. Based on the observed water level at the Pantoloan tidal gauge, the initial water level is set to $2.3 \mathrm{~m}$ above mean sea level (MSL), representing high tide conditions (Pakoksung et al., 2019).

Because of the unknown exact value of soil properties that can be estimated from only the stated empirical equations, this study

175 considers a variation in soil parameters according to the available soil property data (Fig. 4). For example, the measured soil unit weight varies from $\sim 11.7-12.4 \mathrm{~kg} / \mathrm{m}^{3}$ for stratum no. 1 (the first $\sim 3-8 \mathrm{~m}$ of depth from the ground surface) in Lower Palu Bay and $\sim 13.2-15.0 \mathrm{~kg} / \mathrm{m}^{3}$ for stratum no. 2. Regarding the landslide geometry, this study assumes an elliptical sliding surface. The geometry is composed of a major radius (the longer radius of the ellipse) and a minor radius. The major radius is always set equally to 2 times the minor radius. This study varies the major radius from $0.5 \mathrm{~km}$ to $1 \mathrm{~km}$. We perform $\sim 70$ configurations

180 based on these properties, and the final parameter settings for the landslide model are summarized in Table 2.

\subsubsection{Seismic force}

To evaluate the impact of the earthquake, the design horizontal seismic intensity was proposed by the Eq. 5 (Noda et al., 1975): 
where $k$ is the design horizontal seismic intensity, $a$ is the maximum value of the ground surface acceleration in $\mathrm{cm} / \mathrm{s}^{2}$, and $\mathrm{g}$ is the gravitational acceleration, which is equal to $980 \mathrm{~cm} / \mathrm{s}^{2}$. At the Palu site, the ground surface acceleration is approximately 75 $97 \%$ of the gravitational acceleration (https://earthquake.usgs.gov/earthquakes/eventpage/us1000h3p $4 /$ map), which means $k=$ $0.28-0.33$. In this study, a $k$ of 0.30 is applied equally to all Palu Bay areas.

\subsection{Tsunami model}

This study adopted the same tsunami model as used in Pakoksung et al.'s (2019) study. A two-layer computational model,

TUNAMI-N2, was developed to solve nonlinear shallow-water equations with two interfacing layers and kinematic and dynamic boundary conditions at the seafloor, interface, and water surface (Imamura and Imteaz, 1995). The mathematical model used in the TUNAMI-N2 code is made up of a stratified medium of two layers. The first layer is composed of a homogeneous inviscid fluid with a constant density $\rho_{l}$ that represents seawater, while the second layer is composed of a fluidized granular substance with a density $\rho_{s}$ and a porosity $\mu$ that represents air. The mean density of the fluidized debris is assumed to be constant and equal to $\rho_{2}=(1-\mu) \rho_{\sigma+} \mu \rho_{1}$ (Macías et al., 2015). A more detailed explanation is given in Pakoksung et al.'s (2019) study.

\subsection{Topographic data}

Regarding the depth of the considered areas, this analysis used bathymetric data supported by Badan Informasi Geospasial (BIG), Indonesia. This database was developed prior to the Palu tsunami of 2018. BIG provided bathymetric and topographic data for the entire Palu Bay region as well as the adjacent continental areas. The domain was set to a $27 \mathrm{~m}$ bathymetric resolution in the sea, yielding a domain of $1155 \times 810$, which covered the entire Palu Bay area (Fig. 1), and a $1 \mathrm{~m}$ resolution for the nearshore Palu city with the size of $4.051 \times 1.390 \mathrm{~km}^{2}$, resulting in a $4051 \times 1390$ grid. A constant-grid tsunami simulation was solved at each time step of $0.01 \mathrm{~s}$. It should be noted that the terrain data used in this study are adjusted by adding the constant of $2.3 \mathrm{~m}$ due to the lack of inundation area at high tide conditions, as recommended by Pakoksung et al. (2019).

\subsection{Comparison index}

205 To quantitatively compare the measured and estimated runup heights and inundation depths, Aida's (1978) correlation values; the geometric mean; and $K$ and its variance, $\kappa$, are used and described by Eq. 6 and Eq. 7 respectively:

$\log K=\frac{1}{n} \sum_{i=1}^{n} \log k_{i}$

$\log \kappa=\left[\frac{1}{n} \sum_{i=1}^{n}\left(\log k_{i}\right)^{2}-(\log K)^{2}\right]^{0.5}$

where, $k_{i}=R_{i} / H_{i} . R_{i}$ is the field measurement's runup height at point $i . H_{i}$ is the calculated runup height at point $i$ from the

210 simulation, and $n$ is the total amount of data. A $K$ value close to 1 and small $\kappa$ indicates good agreement between the observations and simulations.

\section{Simulation results}

\subsection{Submarine landslides}

This study configured $\sim 70$ cases with variations in soil properties, angle of inclination, and earthquake intensity for the best estimation. A total of 23 submarine landslide events were simulated and are shown in Fig. 6, excluding the proposed 
coastal/submarine landslides collected from past studies. The maximum landslide thickness varied from $\sim 5-20 \mathrm{~m}$. Due to the stronger soil properties, fewer submarine landslides appeared in the Upper Bay, more land failure occurred in the Middle Bay, and the Lower Bay zone was the most vulnerable to the earthquake due to weaker input soil properties. The largest submarine landslide occurred around the nearshore area of Palu city, with a size of $\sim 0.04 \mathrm{~km}^{3}$, which is much smaller than the submarine

220 landslides proposed by Pakoksung et al. (2019) and Nakata et al. (2020).

However, most submarine landslides occurred in the potential areas proposed by past research. Haidarzadeh et al. (2019) proposed possible major submarine landslides along underwater slopes by using backward tsunami ray tracing, in which they placed a point tsunami source at the location of the Pantoloan tide gauge and propagated the tsunami model for 5 minutes (Fig. 6, dashed rectangle). Based on slope stability analysis, this study provided a maximum of 7 submarine landslides that could occur

225 at that location. The largest computed submarine landslide was located around the area suggested by Nakata et al. (2020), as shown in Fig. 6. The lower blue dashed ellipses hint at a large submarine landslide with a volume of $0.07 \mathrm{~km}^{3}$. Moreover, this study found 3 submarine mass failures with a total size of $\sim 0.05 \mathrm{~km}^{3}$ in the mentioned area. By following Nakata et al. (2020), Schambach et al. (2021) modeled submarine mass failure with a size of $\sim 0.026 \mathrm{~km}^{3}$ in a similar area and found good agreement with the nearby observed runups (Fig. 6, yellow ellipse). According to these resulting landslides, this study strongly emphasizes

230 the potential submarine landslides in Lower Palu Bay. In addition, the computed submarine landslides in the mentioned lower dashed ellipse area follow the possible erosion zone after the earthquake occurred when compared to the surveyed postearthquake bathymetry based on Liu et al. (2020).

Unlike the study by Pakoksung et al. (2019), who suggested hypothesized submarine landslides in a northern area outside of Palu Bay, this study found only 2 small mass failures around these locations. This study did not generate any submarine landslide in

235 the upper blue dashed ellipse zone around the Pantoloan tide gauge (Fig. 6), as proposed by Nakata et al. (2020). Moreover, the landslide model failed to simulate landslides in western Palu, as suggested by Carvajal et al. (2019) (zones $I, J, K, L$, and $M$ ) based on slope stability analysis and the available soil properties. However, Sepúlved et al. (2020) insisted on these contributions as the main sources. Therefore, this study needs to combine these submarine landslides with the present simulations to reproduce tsunami events.

\section{$240 \quad 3.2$ Simulated tsunamis}

\subsubsection{Runup heights and inundation depths}

Figure 7 shows the simulated tsunami runup height and the comparison between simulated and observed values. This study compares the calculated runups with the observational runups from government reports and published research, including (1) the Geological Agency of Indonesia (Badan Geologi, 2018)'s report, (2) The agency of Meteorology, Climatology and Geo-physics

245 (BMKG) of Indonesia, (3) Omira et al. (2019), and (4) Widiyanto et al. (2019). These studies' surveys cover all of the study area of this paper around Palu Bay. Overall, the simulated tsunami runup heights vary from $\sim 3.5$ to $13.5 \mathrm{~m}$ on the west coast and $\sim 4.1$ to $11.0 \mathrm{~m}$ on the east coast. Large wave amplitudes are found at the shoreline of the western coast in Middle Palu Bay and the eastern coast in Lower Palu Bay, which indicate slight overestimation in these areas. The comparison index, including the geometric mean $K$ and geometric standard deviation $\kappa \square$ is featured in Fig. 7b. According to the figure, overall, the simulation is

250 overestimated as $K=1.18$, which is $>1.0$, and $\kappa=1.44$ from 98 observations. A comparison with Widiyanto et al. (2019) gives the best results when $K=1.17$ and $\kappa=1.39$ from 27 observation points. The scatter plot in Fig. $7 \mathrm{~b}$ indicates that most of the computed runups are in the range of $\pm 2.1 \square \mathrm{m}$ error. It should be noted that the measured runups from past research were adjusted to our terrain dataset; that is, $2.3 \mathrm{~m}$ was added (Pakoksung et al., 2019). 
The tsunami inundation based on simulated submarine landslides is also evaluated using the evidence of inundation surveyed by 255 past studies, including Badan Geologi's report, Omira et al. (2019), and Widiyanto et al. (2019). The tsunami flow depth apparently follows a similar trend with the runup heights but with more fluctuations. Generally, there are overestimated trends on both sides of the bay (Fig. 8a), and the simulation is slightly overestimated at $K=1.13$, which is $>1.0$. and $\kappa=2.15$ from 62 observations according to Fig. 8b. The inundation depth results show large variances when compared to the surveyed inundations. This study calculates the inundation depths by the simulated runup height subtracted by the topographic terrain with

260 a $27 \mathrm{~m}$ resolution. The coarser resolution may inevitably affect the simulation results. This study also performs a tsunami inundation simulation on Palu city with a 1 m resolution terrain data, which shows a significantly better result. We discuss this result in the next section.

\subsubsection{Inundation area and depths around Palu city}

Palu city, where many buildings for residential, commercial, industrial, governmental, short-term stay and other purposes are located, has been impacted by inundation $\sim 300 \mathrm{~m}$ from the coastlines. Paulik et al. (2019) conducted a high-resolution field survey to measure tsunami inundation heights at 371 building sites and indicated inundation depths ranging from 0.1 to $3.65 \mathrm{~m}$, with a mean of $1.05 \mathrm{~m}$ and a standard deviation of $0.55 \mathrm{~m}$. Moreover, the simulation in this study can slightly overestimate. The calculated inundation depths range from 0.12 to $3.83 \mathrm{~m}$, with a mean of $1.30 \mathrm{~m}$ and a standard deviation of $0.50 \mathrm{~m}$ above the ground. A comparison between the simulated and observed tsunami inundation depths is shown in Fig. 9a. A total of 164 observation spots were selected in this study due to the limited availability of $1 \mathrm{~m}$ resolution terrain data. The comparison index indicates that $K=1.17$ and $\kappa=1.93$, which means that the depths obtained by the simulations slightly outnumber Paulik et al.'s (2019) observed inundation depths (Fig. 9b). Although the comparison was made at different scales, the high resolution of the data resulted in a higher accuracy of the inundation depths.

The boundary of the tsunami inundation area was retrieved from Gusman et al. (2019), who interpreted the boundary from visible tsunami debris in satellite images. The comparison between the observed inundation area in Palu city is shown in Fig. 9c and indicates that the calculated inundation area is $\sim 1.188 \mathrm{~km}^{2}$, while the selected observation of the inundation area is $\sim 0.747$ $\mathrm{km}^{2}$. This means that the simulation result is overestimated by $\sim 59 \%$.

\subsubsection{Pantoloan tide gauge waveform}

The tsunami wave amplitude time series at the Pantoloan tidal gauge with detided sea level is depicted in Fig. 10. The first

280 negative tsunami wave peak of $1.35 \mathrm{~m}$ was reached at the tidal gauge within 6 minutes, followed by the first positive peak of $1.93 \mathrm{~m} 2$ minutes later. Several past studies attempted to reproduce the waveform at the Pantoloan tide gauge. Although there was an argument that the reliability of the 1 minute sampling interval of the tide gauge record did not sufficiently capture the shorter-period characteristics of tsunamis (Carvajal et al. (2019)), many studies have shown agreeable results by reproducing the water level observations at the Pantoloan tide gauge. For example, the model of Haidarzadeh et al. (2019), using purely tectonic

285 sources, performed backward tsunami ray tracing and modeled 5 minute tsunami propagation to indicate 2 potential submarine landslide areas (Fig. 6) to match the waveform at the location of the Pantoloan tide gauge. Nakata et al. (2020) assumed a submarine landslide source near the tide gauge (Fig. 6, upper blue dashed ellipse) to explain the waveform characteristics. Moreover, Pakoksung et al., 2019 suggested that large assumed submarine landslides should be located north outside of the bay to generate the observed waveform characteristics at the Pantoloan tide gauge. Therefore, with calculated submarine landslides

290 based on Hovland's slope stability analysis, this study supports the hypothesized area of Haidarzadeh et al. (2019) and shows that the landslides located in the southern part of Palu Bay affect the water level at the Pantoloan tide gauge. However, the results 
do not show the absolute accuracy of the peak tsunami wave. The proposed submarine landslide sources combined with the observed landslides generate a sooner arrival time and larger peaks of tsunami waves than the recorded data. The simulated waveform has an extreme negative peak of $-3.0 \mathrm{~m}$ at 3 minutes and a positive peak of $2.15 \mathrm{~m}$ at 5 minutes after landslide occurrence (Fig. 10). The peak error percentage is used to indicate the performance of the simulation and can be determined by Eq. 8:

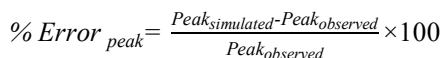

where Peak $k_{\text {simulated }}$ represents the peak calculated from the model simulation and Peak $k_{\text {observed }}$ is the peak of the tsunami wave from the observations. According to the equation, the simulation yields a peak error of $11.40 \%$ and a 3 minute shorter arrival time. It should be noted that this study tried to simulate only the observed submarine landslide sources (as was conducted in Lui et al., 2020), and the results did not show good agreement with the observed waveform.

\subsubsection{Video-inferred waveforms}

Past studies have shown some difficulties in reproducing CCTV-based tsunami characteristics based solely on coseismic sources for every available footage since they were introduced as an observational dataset (Carvajal et al., 2019; Sepúlveda et al., 2020).

305 The observed tsunami waveforms inferred from video footage have short arrival times, and periods of $\sim 2$ minutes resulted in short wavelengths (Carvajal et al., 2019). In general, by visual observation, the results of simulated video-inferred waveforms have even longer arrival times than the waveforms inferred from CCTV footages by judging the first peak of the tsunami wave. Three out of 6 video inferred waveforms had comparable characteristics in southern Palu Bay, including in Talise, the KN Hotel area, and West Palu (Fig. 11), while the simulation results cannot fully explain the observations in northern Palu Bay, Pantoloan

310 and Wani. The simulation demonstrates that an overestimation of calculated landslide sources resulted in more devastating tsunami waves with higher peaks and longer wave periods in southern Palu Bay. The peak errors are $165 \%, 22 \%,-39 \%, 32 \%$, $36 \%$ and $-8 \%$ for Dupa, the KN Hotel, Pantoloan, Talise, Wani and West Palu, respectively. The time of the peak in Dupa, Pantoloan, Wani and West Palu is approximately $0.45,1.50,2.95$ and 0.21 minutes before the observations, while the peak time in the KN Hotel and Talise occur shortly after the observation, by -1.30 and -0.10 minutes, respectively. However, there is

315 uncertainty regarding the timing of the video-inferred time series because the video footage was apparently captured promptly after the tsunami rather than earthquake shaking. The uncertainty may also result in \pm 15 to $\pm 30 \mathrm{~s}$ of arrival time error in this study (Sepúlveda et al., 2020).

\section{Discussions}

Regarding the model parameters for simulating submarine landslide sources, we configured the model parameters, i.e., statured possible to the existing data. Slope failures can be found only in some steep slope areas inside Palu Bay. The model fails to comprehensively reproduce the observed landslides, which are located near Palu Bay, for both location and mass size. Based on Hovland's slope stability analysis and measured soil properties, there is no slope failure in the mentioned nearshore or coastal areas. Despite modeling failure, this study can simulate submarine landslides in the potential areas proposed by Haidarzadeh et al. (2019), Nakata et al. (2020), and Schambach et al. (2021), which can imply that based on the supported theory, undiscovered submarine landslides in those areas are possible, especially a large mass failure with a size of at least $0.05 \mathrm{~km}^{3}$ in southern Palu Bay (Fig. 6, blue dashed ellipse). However, this study overproduced submarine landslide sources in southern Palu Bay according to tsunami simulation results. The runup heights, inundation depths, waveforms at the Pantoloan tide gauge, video footage-based 
waveforms, inundation area and depths in Palu city all generally show overestimated trends. In particular, a comparison with observations shows obvious overestimation of the simulation results of the southern Palu areas. These results imply that the real soil properties have a strong spatial variation. The soil properties in the simulation of southern Palu Bay, which was sampled near the Palu River, are probably weaker than the realistic conditions, resulting in many larger submarine mass failures than the observed failures. In addition, this study cannot reproduce the landslide sources around nearshore Palu Bay, where past studies strongly indicate that they mainly contribute to the Palu tsunami, i.e., zones $I, J, K, L$, and $M$ (Carvajal et al., 2019; Sepúlveda et

335 al., 2020), and zones $B$ and $C$ (Liu et al., 2020; Schambach et al., 2021) because these areas probably have stronger soil properties than those in the simulation. Notably, a landslide source in the nearshore area around the Pantoloan tide gauge, as proposed by Nakata et al. (2020) (Fig. 6, upper blue dashed ellipse), which still cannot be explained by this study, also needs to be addressed.

This study applied a constant earthquake intensity to the entire domain; however, in reality, earthquake intensity varies spatially.

340 The peak intensity was located in southeastern Palu Bay according to the USGS. It should be noted that we tried to vary the earthquake intensity between 3 study zones, with a maximum intensity of $76 \%$ for Upper Palu and $80 \%$ intensity for Middle and Lower Palu Bay, but the results did not show a significant difference from those when a constant intensity was applied.

There is controversy regarding the Hovland method. Hovland's slope stability ignores the resistant force acting on the surface and the friction between soil columns and considers only the force acting on the slip surface. This leads to a smaller safety factor

345 when compared to the other methods (e.g., Janbu) (Ahmed et al., 2014); in other words, Hovland's method tends to give an overestimated output. However, this method is simple and suiTable for calculation in a large area or a high-resolution terrain. There are alternative methods to tackle the problem of overestimating submarine landslides, such as the Bishop and Janbu methods. Hungr et al. (1989) stated that the simplified Bishop method offers a simple and efficient alternative that is applicable to a wide range of practical problems.

350 Further field observations of submarine landslide sources are required to confirm this study's results, especially for submarine landslides in the deep Lower Palu Bay, as suggested by past studies and emphasized by this study. Field observations are also needed to confirm the soil property estimations used in the study area.

Further research should focus on the variation in the time of landslide initiation. This study assumed that all slope failures occur at the same time and start immediately after the earthquake, which may not reflect reality, as there is potentially a difference in

355 the time at which a landslide starts to move. Adding coseismic sources or applying the results from the fault-slip model may help improve this study; Sepúlveda et al., 2020 showed that the combination of earthquake-triggered landslides and the inverted coseismic ground displacements measured with InSAR can reproduce the Palu tsunami with good agreement.

\section{Conclusions}

Rather than employing a trial-and-error approach to the generation of hypothesized landslide sources, this study applied a

360 landslide model based on slope stability analysis for the first time to provide a better understanding of the potential submarine landslide-induced tsunami phenomenon. The simulated tsunami that was triggered by modeled submarine landslide sources based on Hovland's 3D slope stability analysis with observational soil property data and configured landslide geometry shows that the submarine landslide in southern Palu Bay is consistent with the past study; however, the magnitudes of simulated submarine landslides are overestimated, resulting in an overestimation of tsunami parameters, including runup height and

365 inundation depths, around Palu Bay and Palu city. This implies that the measured soil parameters inland of Palu Bay used in this study cannot fully explain the observed landslides. It is difficult to validate the simulation results according to all the available 
observational data, including tsunami runup and inundation depth around Palu Bay and Palu city, water level at Pantoloan tide gauge, and video footage-based waveforms. The simulation results still do not fully explain the observational data, especially the flow depth across Palu Bay. Field observations of submarine landslides, especially in southern Palu, are needed to confirm the results of this study. In future studies, more accurate landslide simulations should be used by applying a more realistic configuration of the landslide thickness, soil parameters and landslide geometry or dividing the study zones into zones with finer resolution. Additionally, the various landslide occurrence times should also be investigated, as strongly recommended by previous literature.

\section{Data availability}

The data used in this study could be requested from the corresponding authors. The author would like to support the interested researchers for further research.

\section{Author contributions}

CS and AS initiated the original idea and conceptualized research. CS and KP performed the modelling with input from CA. SF, SM and KT supported the original code of landslide model. KP, FI supported the tsunami propagation code. The simulation results were discussed among all the co-authors. CS wrote the draft with the contribution from AS, TN, YN, RT, SI, YM.

\section{Competing interests}

The authors declare that they have no conflict of interest.

\section{Acknowledgments}

The authors would like to thank the Center for Volcanology and Geological Hazard Mitigation, Geological Agency of Indonesia

385 for providing the observational data and tsunami flow depth data used to validate the tsunami models of the 2018 Palu tsunami, and the Coastal Disaster Mitigation Division, Ministry of Marine Affairs and Fisheries, Jakarta, Indonesia for issuing tide gauge records at Pantoloan. A special thanks to Japan International Cooperation Agency (JICA) for the support of high resolution of digital elevation model.

\section{References}

390 Aida, I.: Reliability of a tsunami source model derived from fault parameters. J. Phys. Earth., 26, 57-73, 1978.

Ahmed, A., Ugai, K., and Yang, Q. Q.: Assessment of 3D Slope Stability Analysis Methods Based on 3D Simplified Janbu and Hovland Methods, Int. J. Geomech., 12, 81-89, https://doi.org/10.1061/(asce)gm.1943-5622.0000117, 2012.

Arikawa, T., Muhari, A., Okumura, Y., Dohi, Y., Afriyanto, B., Sujatmiko, K. A., and Imamura, F.: Coastal Subsidence Induced Several Tsunamis During the 2018 Sulawesi Earthquake, J. Disaster Res., 13, sc20181204, https://doi.org/10.20965/jdr.2018.sc20181204, 2018.

Badan Geologi: DI BALIK PESONA PALU: Anomali Perilaku Gelombang Tsunami, Badan Geologi, Baundung Indonesia, 2018. (in Indonesia) 
Carvajal, M., Araya-Cornejo, C., Sepúlveda, I., Melnick, D., and Haase, J. S.: Nearly Instantaneous Tsunamis Following the Mw 7.5 2018 Palu Earthquake, Geophys. Res. Lett., 46, 5117-5126, https://doi.org/10.1029/2019GL082578, 2019. Palu-Koro Fault and the pattern of damage caused by the 2018 Sulawesi Earthquake using HVSR inversion, Geol. Soc. London, Spec. Publ., SP501-2019-70, https://doi.org/10.1144/sp501-2019-70, 2020.

Frederik, M. C. G., Udrekh, Adhitama, R., Hananto, N. D., Asrafil, Sahabuddin, S., Irfan, M., Moefti, O., Putra, D. B., and Riyalda, B. F.: First Results of a Bathymetric Survey of Palu Bay, Central Sulawesi, Indonesia following the Tsunamigenic Earthquake of 28 September 2018, Pure Appl. Geophys., 176, 3277-3290, https://doi.org/10.1007/s00024-019-02280-7, 2019.

Goda, K., Mori, N., Yasuda, T., Prasetyo, A., Muhammad, A., and Tsujio, D.: Cascading Geological Hazards and Risks of the 2018 Sulawesi Indonesia Earthquake and Sensitivity Analysis of Tsunami Inundation Simulations, Front. Earth Sci., 7, 116, https://doi.org/10.3389/feart.2019.00261, 2019.

Goto, C., Ogawa, Y., Shuto, N., and Imamura, F.: Numerical method of tsunami simulation with the leap-frog scheme. Intergovernmental Oceanogr. Comm. UNESCO Man. Guides 35, 126, 1997.

Gusman, A. R., Supendi, P., Nugraha, A. D., Power, W., Latief, H., Sunendar, H., Widiyantoro, S., Daryono, Wiyono, S. H., Hakim, A., Muhari, A., Wang, X., Burbidge, D., Palgunadi, K., Hamling, I., and Daryono, M. R.: Source model for the tsunami inside palu bay following the 2018 palu earthquake, Indonesia, Geophys. Res. Lett., 46, 1-10, https://doi.org/10.1029/2019g1082717, 2019.

Hadi, S. and Kurniawati, E.: Jumlah Korban Tewas Terkini, Gempa dan Tsunami Palu 2.113 Orang, available at: https://nasional.tempo.co/read/1138400/jumlah-korban-tewasterkini, 2018, last access: 20 March 2021. (in Bahasa Indonesia)

Hébert, H., Heinrich, P., Schindelé, F., and Piatanesi, A.: Far-field simulation of tsunami propagation in the Pacific Ocean: impact on the Marquesas Islands (French Polynesia). J. Geophys. Res. Oceans 106, 9161-9177. doi:10.1029/2000jc000552, 2001.

Heidarzadeh, M. O. H., Uhari, A. B. M., and Ijanarto, A. N. B. W.: Insights on the Source of the 28 September 2018 Sulawesi Tsunami, Indonesia Based on Spectral Analyses and Numerical Simulations. Pure Appl. Geophys., 176, 25-43, https://doi.org/10.1007/s00024-018-2065-9, 2019.

Heinrich, P. H., Piatanesi, A., and He'bert, H.: Numerical modelling of tsunami generation and propagation from submarine slumps: The 1998 Papua New Guinea event, Geophys, 145, 97-111, 2001.

Heinrich, P., Schindele, F., Guibourg, S., and Ihmlé, P. F.: Modeling of the February 1996 Peruvian tsunami. Geophys. Res. Lett. 25, 2687-2690, doi:10.1029/98g101780, 1998.

Hovland, H. J.: Three-dimensional slope stability analysis method, J. Geotech. Engrg. Div., 103(9), 971-986, 1977.

Horspool, N., Pranantyo, I., Griffin, J., Latief, H., Natawidjaja, D. H., Kongko, W., Cipta, A., Bustaman, B., Anugrah, S. D., and Thio, H. K.: A probabilistic tsunami hazard assessment for Indonesia. Natural Hazards and Earth System Sciences, 14(11), 3105-3122, https://doi.org/10.5194/nhess-14-3105-2014, 2014.

Imamura, F., \& Imteaz, M. A.: Long waves in two-layers: Governing equations and numerical model. Sci. Tsunami Hazards, 13(1), 3-24, 1995.

435 Jamelot, A. J., Ailler, A. G., Einrich, P. H. H., Allage, A. V, and Hampenois, J. C.: Tsunami Simulations of the Sulawesi Mw 7.5 Event: Comparison of Seismic Sources Issued from a Tsunami Warning Context Versus Post-Event Finite Source. Pure Appl. Geophys., 176, 3351-3376. https://doi.org/10.1007/s00024-019-02274-5, 2019. 
Kirar, B., Maheshwari, B.K. \& Muley, P. Correlation Between Shear Wave Velocity (Vs) and SPT Resistance (N) for Roorkee Region. Int. J. of Geosynth. and Ground Eng. 2, 9. https://doi.org/10.1007/s40891-016-0047-5, 2016.

Kumar, R., Bhargava, K., and Choudhury, D.: Estimation of Engineering Properties of Soils from Field SPT Using Random Number Generation, Ina. Lett., 1, 77-84, https://doi.org/10.1007/s41403-016-0012-6, 2016.

Liu, P. L., Higuera, P., Husrin, S., Prasetya, G. S., Prihantono, J., Diastomo, H., Pryambodo, D. G., and Susmoro, H.: Coastal landslides in Palu Bay during 2018 Sulawesi earthquake and tsunami. Landslides, 17, 2085-2098, https://doi.org/10.1007/s10346-020-01417-3, 2020.

Løvholt, F., Glimsdal, S., Harbitz, C. B., Horspool, N., Smebye, H., de Bono, A., and Nadim, F.: Global tsunami hazard and exposure due to large co-seismic slip, Int. J. Disaster Risk Reduct., 10, 406-418, https://doi.org/10.1016/j.jidrr.2014.04.003, 2014.

Macías, J., Vázquez, J. T., Fernández-Salas, L. M., González-Vida, J. M., Bárcenas, P., Castro, M. J., Díaz-del-Río, V., and Alonso, B.: The Al-Borani submarine landslide and associated tsunami. A modelling approach, Mar. Geol., 361, 79-95, https://doi.org/10.1016/j.margeo.2014.12.006, 2015.

Mikami, T., Shibayama, T., Esteban, M., Takabatake, T., Nakamura, R., Nishida, Y., Achiari, H., Rusli, Marzuki, A. G., Marzuki, M. F. H., Stolle, J., Krautwald, C., Robertson, I., Aránguiz, R., and Ohira, K.: Field Survey of the 2018 Sulawesi Tsunami: Inundation and Run-up Heights and Damage to Coastal Communities, Pure Appl. Geophys., 176, 3291-3304, https://doi.org/10.1007/s00024-019-02258-5, 2019.

Nakata, K., Katsumata, A., and Muhari, A.: Submarine landslide source models consistent with multiple tsunami records of the 2018 Palu tsunami, Sulawesi, Indonesia, Earth, Planets Sp., 72, https://doi.org/10.1186/s40623-020-01169-3, 2020.

National Geophysical Data Center / World Data Service (NGDC/WDS): NCEI/WDS Global Significant Earthquake Database. NOAA National Centers for Environmental Information. http://doi:10.7289/V5TD9V7K, last access: 23 January 2021

Noda, S., Kami, T., Chiba, T.: Seismic Intensity and Ground Acceleration of Gravity Dam, Report of Port and Airport Research Institute. 14(4), 1975. (In Japanese).

Oldrich Hungr, F. M. Salgado, and P. M. Byrne. Evaluation of a three-dimensional method of slope stability analysis. Can. Geotech. J., 26, 679-686, https://doi.org/10.1139/t89-079, 1989.

Omira, R., Dogan, G. G., Hidayat, R., Husrin, S., Prasetya, G., Annunziato, A., Proietti, C., Probst, P., Paparo, M. A., Wronna, M., Zaytsev, A., Pronin, P., Giniyatullin, A., Putra, P. S., Hartanto, D., Ginanjar, G., Kongko, W., Pelinovsky, E., and Yalciner, A. C.: The September 28th, 2018, Tsunami In Palu-Sulawesi, Indonesia: A Post-Event Field Survey, Pure Appl. Geophys., 176, 1379-1395, https://doi.org/10.1007/s00024-019-02145-z, 2019.

Pakoksung, K., Suppasri, A., Imamura, F., Athanasius, C., Omang, A., and Muhari, A.: Simulation of the Submarine Landslide Tsunami on 28 September 2018 in Palu Bay, Sulawesi Island, Indonesia, Using a Two-Layer Model, Pure Appl. Geophys., 176, 3323-3350, https://doi.org/10.1007/s00024-019-02235-y, 2019.

Pang, Q.: Situation update no. 12 M 7.4 Earthquake \& Tsunami Sulawesi, Indonesia. https://reliefweb.int/sites/reliefweb.int/files/resources/AHA-Situation_Update-no12-SulawesiEQ-rev.pdf, lass access: 20 March 2021.

Paris, A., Heinrich, P., Paris, R. Abadie, S.: The December 22, 2018 Anak Krakatau, Indonesia, Landslide and Tsunami: Preliminary Modeling Results. Pure Appl. Geophys. 177, 571-590, https://doi.org/10.1007/s00024-019-02394-y, 2020.

Patria, A., Putra, P.S.: Development of the Palu-Koro Fault in NW Palu Valley, Indonesia. Geosci. Lett. 7, 1, https://doi.org/10.1186/s40562-020-0150-2, 2020. 
Paulik, R., Gusman, A., Williams, J. H., Pratama, G. M., Lin, S. lin, Prawirabhakti, A., Sulendra, K., Zachari, M. Y., Fortuna, Z. E. D., Layuk, N. B. P., and Suwarni, N. W. I.: Tsunami Hazard and Built Environment Damage Observations from Palu City after the September 282018 Sulawesi Earthquake and Tsunami. Pure Appl. Geophys., 176, 3305-3321. https://doi.org/10.1007/s00024-019-02254-9, 2019

Sassa, S. and Takagawa, T.: Liquefied gravity flow-induced tsunami: first evidence and comparison from the 2018 Indonesia Sulawesi earthquake and tsunami disasters, 16, 195-200, https://doi.org/10.1007/s10346-018-1114-x, 2019.

Schambach, L., Grilli, S. T., and Tappin, D. R.: New High-Resolution Modeling of the 2018 Palu Tsunami, Based on Supershear Earthquake Mechanisms and Mapped Coastal Landslides, Supports a Dual Source, Front. Earth Sci., 8, 1-22, https://doi.org/10.3389/feart.2020.598839, 2021

Sepúlveda, I., Haase, J. S., Carvajal, M., Xu, X., and Liu, P. L. F.: Modeling the Sources of the 2018 Palu, Indonesia, Tsunami Using Videos From Social Media, J. Geophys. Res. Solid Earth, 125, 1-22, https://doi.org/10.1029/2019JB018675, 2020.

Suppasri, A., Goto, K., Muhari, A., Ranasinghe, P., Riyaz, M., Affan, M., Mas, E., Yasuda, M., and Imamura, F.: A Decade After the 2004 Indian Ocean Tsunami: The Progress in Disaster Preparedness and Future Challenges in Indonesia, Sri Lanka, Thailand and the Maldives, Pure Appl. Geophys., 172, 3313-3341, https://doi.org/10.1007/s00024-015-1134-6, 2015.

Takagi, H., Pratama, M. B., Kurobe, S., Esteban, M., Aranguiz, R., and Ke, B.: Analysis of generation and arrival time of landslide tsunami to palu city due to the 2018 sulawesi earthquake. Landslides, 16, 983-991, https://doi.org/10.1007/s10346-019-01166-y, 2019

Ulrich, T.: Coupled, Physics-Based Modeling Reveals Earthquake Displacements are Critical to the 2018 Palu, Sulawesi Tsunami. Pure Appl. Geophys., 176, 4069-4109, https://doi.org/10.1007/s00024-019-02290-5, 2019.

US Geological Survey $\mathrm{M} \quad 7.5-70 \quad \mathrm{~km} \quad \mathrm{~N} \quad$ of $\quad$ Palu, $\quad$ Indonesia. https://earthquake.usgs.gov/earthquakes/eventpage/us1000h3p4/executive, lass access: 23 January 2021.

Widiyanto, W., Santoso, P. B., Hsiao, S. C., and Imananta, R. T.: Post-event field survey of 28 September 2018 Sulawesi earthquake and tsunami, Nat. Hazards Earth Syst. Sci., 19, 2781-2794, https://doi.org/10.5194/nhess-19-2781-2019, 2019. 
Table 1 Summary of the main characteristics of the 2018 Palu event and tsunami reported in previous literature

\begin{tabular}{|c|c|c|c|c|c|c|c|c|c|}
\hline \multirow[t]{2}{*}{$\overline{\text { Study }}$} & \multirow[t]{2}{*}{ Numerical Model(s) } & \multicolumn{2}{|c|}{ Source of Tsunami } & \multicolumn{2}{|c|}{ Source of Landslide Data } & \multicolumn{4}{|c|}{ Verification Data } \\
\hline & & Landslide & Earthquake & Observations & $\begin{array}{l}\text { Assumed/ } \\
\text { Hypothesized } \\
\text { Landslides }\end{array}$ & $\begin{array}{l}\text { Tide } \\
\text { Gauge }\end{array}$ & $\begin{array}{c}\text { Inundation } \\
\text { area }\end{array}$ & $\begin{array}{c}\text { Run-up } \\
\text { Height/ } \\
\text { Inundation } \\
\text { depth }\end{array}$ & $\begin{array}{c}\text { Video } \\
\text { Footage }\end{array}$ \\
\hline $\begin{array}{l}\text { Heidarzadeh et al. } \\
2019\end{array}$ & COMCOT & & $\circ$ & & & $\circ$ & & & \\
\hline $\begin{array}{l}\text { Carvajal, M. et al., } \\
2019\end{array}$ & COMCOT & & $\circ$ & $\circ$ & & $\circ$ & & $\circ$ & \\
\hline Takagi et al., 2019 & Delft-3D & & $\circ$ & & $\circ$ & $\circ$ & & $\circ$ & \\
\hline $\begin{array}{l}\text { Pakoksung et al. } \\
2019\end{array}$ & TUNAMI-N2 & $\circ$ & & $\circ$ & $\circ$ & ० & $\circ$ & $\circ$ & \\
\hline Jamelot et al.,2019 & $\begin{array}{l}\text { NLSWE (Heinrich } \\
\text { et al. }(1998) \text { and } \\
\text { Hebert et al. }(2001))\end{array}$ & & $\circ$ & & & ० & $\circ$ & $\circ$ & \\
\hline Ulrich et al. 2019 & $\begin{array}{c}\text { Coupled EQ + tsunami } \\
\text { model, Seisol + } \\
\text { StormFlash2D }\end{array}$ & & $\circ$ & & & $\circ$ & & $\circ$ & \\
\hline $\begin{array}{l}\text { Gusman et al. } \\
2019\end{array}$ & COMCOT & $\circ$ & $\circ$ & $\circ$ & & $\circ$ & $\circ$ & $\circ$ & \\
\hline Goda et al., 2019 & $\begin{array}{c}\text { NLSWE } \\
\text { (Goda } \text { et al., 1997) }\end{array}$ & & & & & $\circ$ & $\circ$ & & \\
\hline Nakata et al. 2020 & JAGURS & $\circ$ & $\circ$ & & $\circ$ & $\circ$ & & $\circ$ & $\circ$ \\
\hline Liu et al., 2020 & COMCOT & $\circ$ & & $\circ$ & & $\circ$ & & & $\circ$ \\
\hline $\begin{array}{l}\text { Sepúlveda et al., } \\
2020\end{array}$ & COMCOT & $\circ$ & $\circ$ & $\circ$ & & $\circ$ & & $\circ$ & o \\
\hline $\begin{array}{l}\text { Schambach et al., } \\
2021\end{array}$ & NHWAVE/FUNWAVE & $\circ$ & $\circ$ & ० & $\circ$ & ० & & ० & ० \\
\hline Present Study & $\begin{array}{c}\text { Numerical model based } \\
\text { on Hovland's (1977) + } \\
\text { TUNAMI-N2 }\end{array}$ & $\circ$ & & $\circ$ & ० & ० & $\circ$ & $\circ$ & ० \\
\hline
\end{tabular}


https://doi.org/10.5194/nhess-2021-170

Preprint. Discussion started: 22 June 2021

(c) Author(s) 2021. CC BY 4.0 License.

505 Table 2 Parameter settings for the landslide model

\begin{tabular}{|c|c|c|c|}
\hline Soil Properties & Upper Bay & Lower Bay & Middle Bay \\
\hline \multicolumn{4}{|l|}{ Soil Parameter (Stratum no. 1) } \\
\hline Stratum depth (m) & 3.0 & 6.0 & 3.0 \\
\hline \multicolumn{4}{|l|}{ Saturated Condition } \\
\hline - $\quad$ Cohesion $(\mathrm{kPa})$ & 12.0 & 7.5 & 5.0 \\
\hline - $\quad$ Internal Friction Angle (degree) & 15.0 & 10.0 & 7.0 \\
\hline - $\quad$ Unit Weight $\left(\mathrm{kN} / \mathrm{m}^{3}\right)$ & 11.5 & 12.4 & 11.7 \\
\hline \multicolumn{4}{|l|}{ Soil Parameter (Stratum no. 2) } \\
\hline Stratum depth (m) & $\overline{7.0}$ & 14.0 & 12.0 \\
\hline \multicolumn{4}{|l|}{ Saturated Condition } \\
\hline - $\quad$ Cohesion $(\mathrm{kPa})$ & 17.5 & 23.7 & 20.0 \\
\hline - $\quad$ Internal Friction Angle (degree) & 24.0 & 28.3 & 24.0 \\
\hline - Unit Weight $\left(\mathrm{kN} / \mathrm{m}^{3}\right)$ & 14.3 & 13.2 & 13.0 \\
\hline \multicolumn{4}{|l|}{ Underground } \\
\hline Groundwater Table Offset (m) & 0.0 & 0.0 & 0.0 \\
\hline Mean Sea Level (+msl) & 2.3 & 2.3 & 2.3 \\
\hline
\end{tabular}

\section{Base layer}

Dry Condition

- Cohesion (kPa) $\quad 50.0$

- $\quad$ Internal friction Angle (degree) $\quad 30.0$

Saturated Condition

- Cohesion $(\mathrm{kPa}) \quad 20.0$

- Internal Friction Angle (degree) $\quad 25.0$

Ellipsoid Geometry

Maximum Major Radius

Actual Length (m)

Minimum Minor Radius

Actual Length (m)

\begin{tabular}{lll}
30 & 30 & 30 \\
810.0 & 810.0 & 810.0 \\
15 & 15 & 15 \\
405.0 & 405.0 & 405.0 \\
\hline
\end{tabular}

Earthquake Intensity

Acceralation $(\% \mathrm{~g})\left(\mathrm{g}=980 \mathrm{~cm} / \mathrm{s}^{2}\right)$

$70 \%$

$\begin{array}{ll}50.0 & 50.0\end{array}$

$30.0 \quad 30.0$

Horizontal seismic intensity, $\mathrm{k}$

$70 \%$
0.30

$73 \%$

$70 \%$

.30

0.30

0.30 


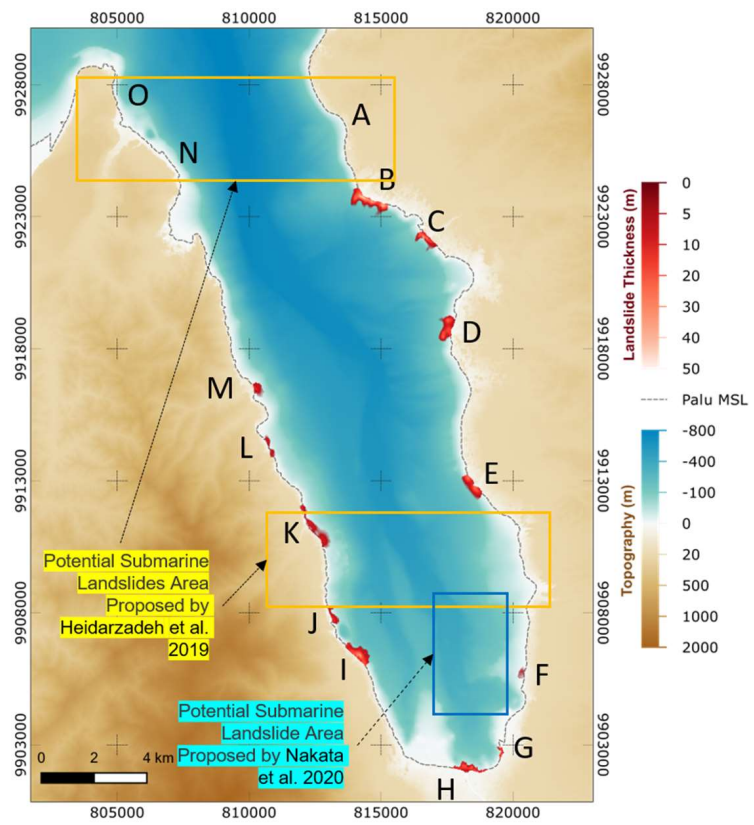

Figure 1 Literature review of observed landslides: A-O represents the locations of observed coastal landslides, and the Table summarizes landslides used/proposed in each study. The areas defined by yellow rectangles depict the potential submarine landslide areas proposed by Haidarzadeh et al. (2019), and the blue rectangle depicts the potential submarine landslide area proposed by Nakata et al. (2020).

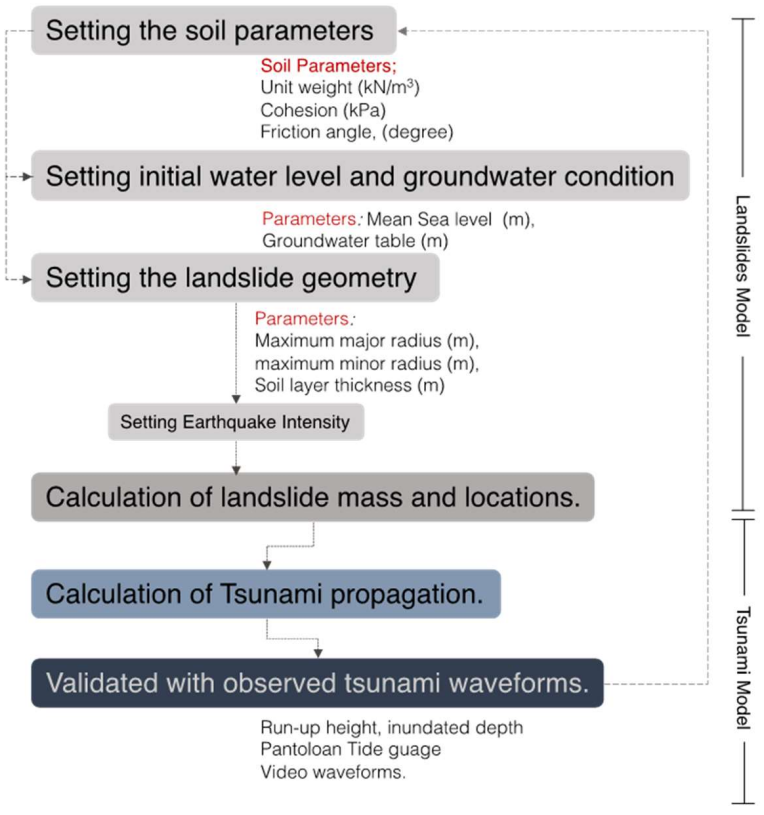

Figure 2 Diagram of modeling procedures. 
(a)

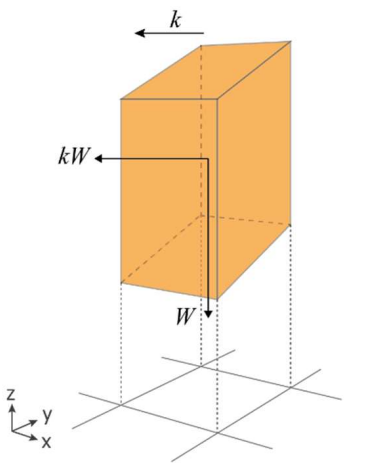

top view

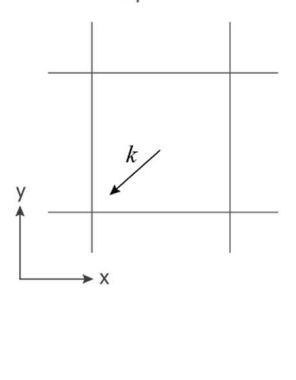

(b)

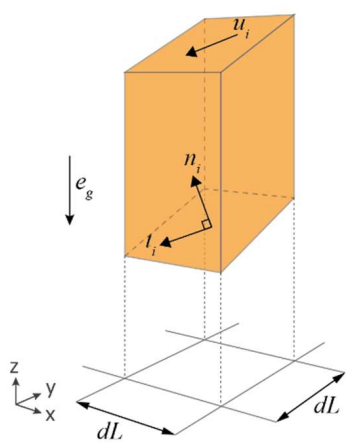

Figure 3 Diagram of soil mass components; (a) design horizontal seismic intensity and direction of the soil mass. (b) Shape of the soil mass 515 and directional vectors used for calculation.

\begin{tabular}{cccccc}
\hline Site no. 504 & & & & & \\
\hline Thickness $(\mathrm{m})$ & $\begin{array}{c}\text { Depth } \\
(\mathrm{m})\end{array}$ & $\begin{array}{c}\mathrm{V}_{\mathrm{p}} \\
(\mathrm{m} / \mathrm{s})\end{array}$ & $\begin{array}{c}\mathrm{V}_{\mathrm{s}} \\
(\mathrm{m} / \mathrm{s})\end{array}$ & $\begin{array}{c}\text { Unit Weight } \\
\left(\mathrm{kg} / \mathrm{m}^{3}\right)\end{array}$ & $\begin{array}{c}\text { STP Blow Counts, } N \\
(\text { Kirar et al.,2016) }\end{array}$ \\
\hline 1.24 & 1.24 & 317.85 & 169.59 & 12.42 & 4.69 \\
1.75 & 2.99 & 569.24 & 257.80 & 13.32 & 15.79 \\
\hline
\end{tabular}

\begin{tabular}{|c|c|c|c|c|c|}
\hline \multicolumn{6}{|l|}{ Site No. 402} \\
\hline Thickness (m) & $\begin{array}{l}\text { Depth } \\
(\mathrm{m})\end{array}$ & $\begin{array}{c}V_{p} \\
(m / s)\end{array}$ & $\begin{array}{c}V_{s} \\
(m / s)\end{array}$ & $\begin{array}{l}\text { Unit Weight } \\
\left(\mathrm{kg} / \mathrm{m}^{3}\right)\end{array}$ & $\begin{array}{l}\text { STP Blow Counts, } N \\
\text { (Kirar et al.,2016) }\end{array}$ \\
\hline 1.06 & 1.06 & 325.57 & 106.13 & 11.30 & 1.21 \\
\hline 1.39 & 2.45 & 383.94 & 196.24 & 11.56 & 7.16 \\
\hline 3.33 & 5.78 & 495.40 & 205.06 & 17.07 & 8.13 \\
\hline
\end{tabular}

\begin{tabular}{|c|c|c|c|c|c|}
\hline \multicolumn{6}{|l|}{ Site No. 1001} \\
\hline Thickness (m) & $\begin{array}{l}\text { Depth } \\
(\mathrm{m})\end{array}$ & $\begin{array}{l}V_{p} \\
(\mathrm{~m} / \mathrm{s})\end{array}$ & $\begin{array}{c}V_{s} \\
(\mathrm{~m} / \mathrm{s})\end{array}$ & $\begin{array}{l}\text { Unit Weight } \\
\left(\mathrm{kg} / \mathrm{m}^{3}\right)\end{array}$ & $\begin{array}{l}\text { STP Blow Counts, } N \\
\text { (Kirar et al.,2016) }\end{array}$ \\
\hline 1.55 & 1.55 & 106.29 & 64.58 & 10.89 & 0.29 \\
\hline 7.03 & 8.58 & 272.78 & 153.62 & 11.83 & 3.52 \\
\hline 2.05 & 10.63 & 433.74 & 200.40 & 13.10 & 7.61 \\
\hline
\end{tabular}

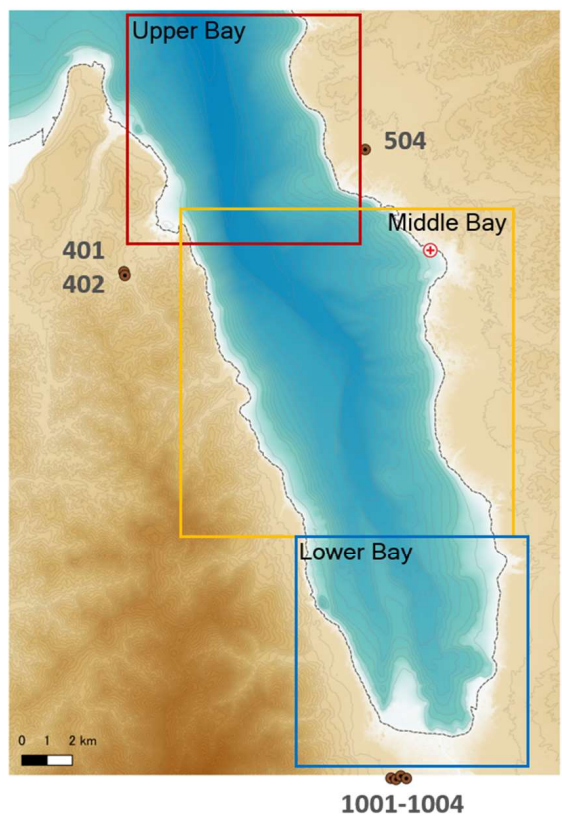

Figure 4 Soil condition data for observation site nos. 1001, 402 and 504 and the Paly Bay zones delineated by the soil properties. The Table includes the shear-wave velocity profile $\mathrm{P}\left(V_{p}\right)$ and $\mathrm{S}\left(V_{s}\right)$ parameters inferred from HVSR microtremor inversion, as well as the soil density over the soil depth and the soil thickness in each layer. 
https://doi.org/10.5194/nhess-2021-170

Preprint. Discussion started: 22 June 2021

(c) Author(s) 2021. CC BY 4.0 License.
Natural Hazards and Earth System Sciences

Discussions

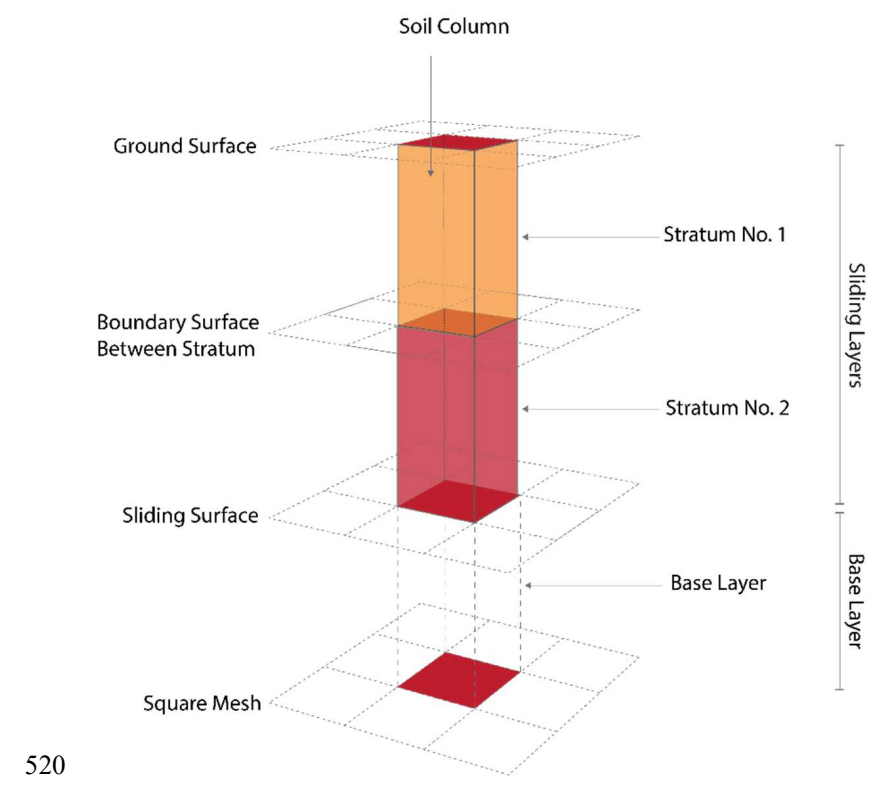

Figure 5 Diagram of the underground soil column structure in the model.

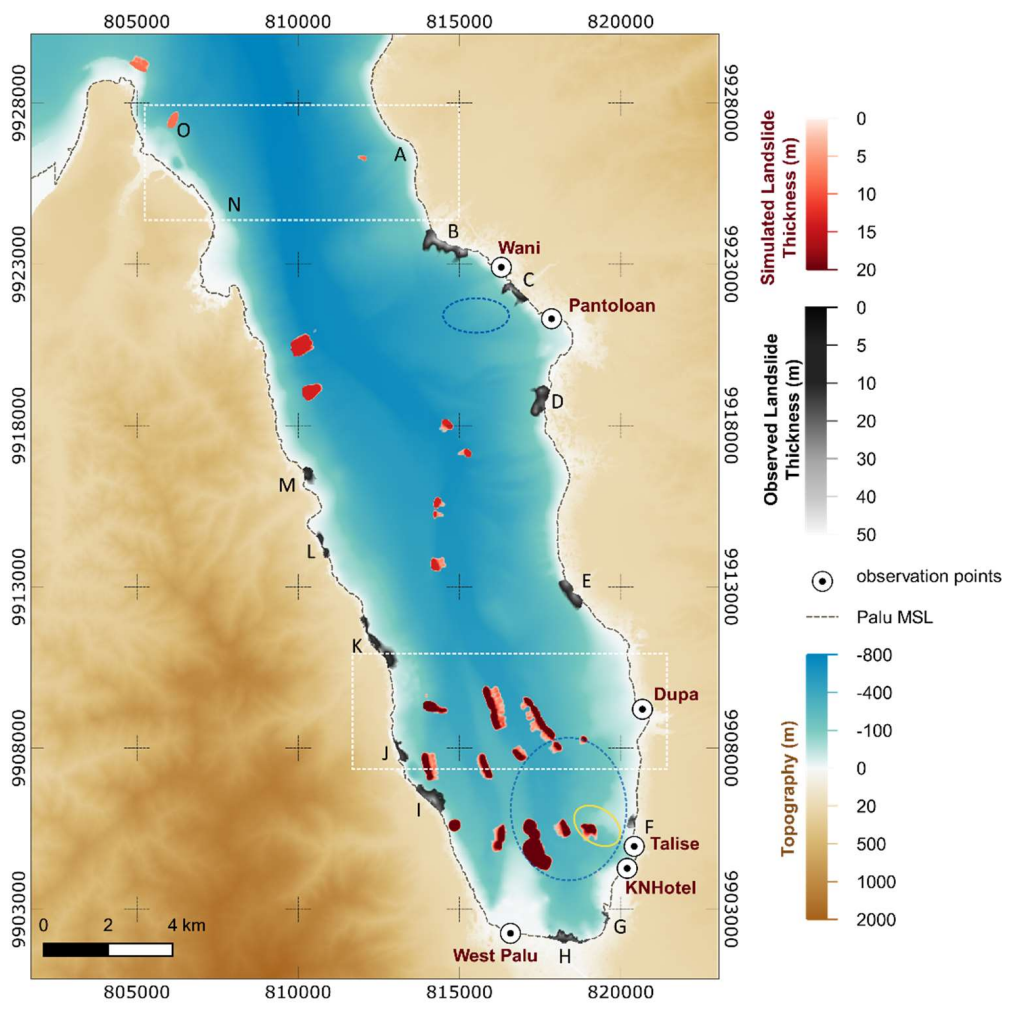


Figure 6 Simulated submarine landslides calculated based on Hovland's slope stability analysis and surveyed coastal/submarine landslides in previous literature. The white and red color bar indicates the simulated landslide thickness for each grid ( $27 \mathrm{~m}$ resolution), and the black and white color bar indicates the observed landslide thickness. The dashed rectangles represent the potential submarine landslide areas proposed by Haidarzadeh et al. (2019), the dashed ellipse represents that proposed by Nakata et al. (2020), and the yellow ellipse represents that proposed by Schambach et al. (2021). The dots represent the video-inferred waveform observation points. A-O indicate the observed landslides collected from previous studies.

(a)

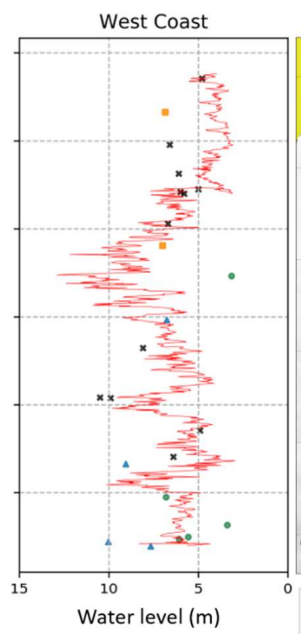

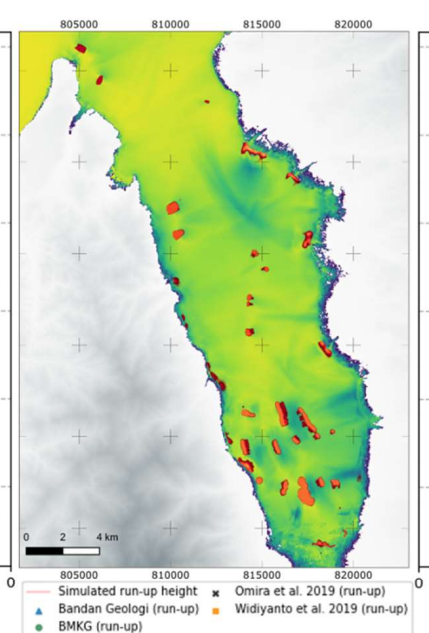
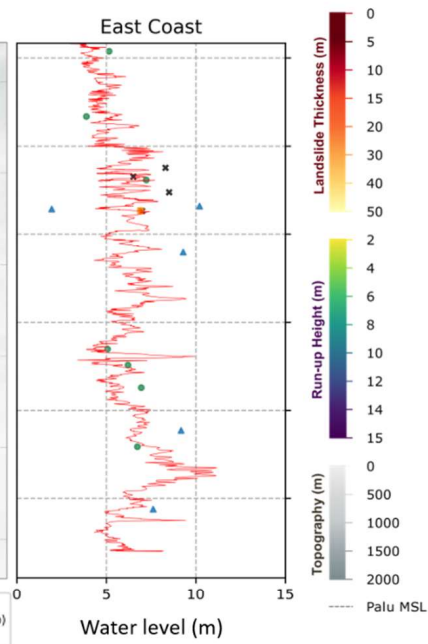

Run-up height simulation and observation (m. +MSL)

(b)

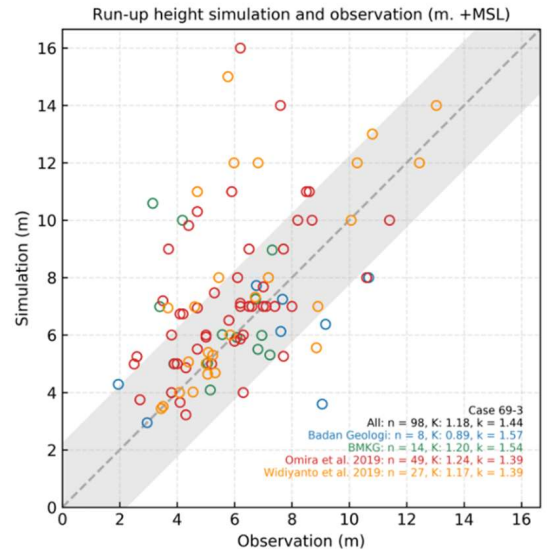

530 Figure 7 Simulated tsunami runup heights resulting from the modeled submarine landslides based on Hovland's slope stability analysis and combined with past studies' observed submarine landslides. (a) Calculated maximum tsunami amplitude (center) with the maximum calculated tsunami amplitude (red line) at the shoreline of the western coast (left) and the eastern coast (right), and the measured runup heights from Badan Geologi's report (blue triangles), BMKG (green circles), Omira et al. (2019) (crosses), and Widiyanto et al. (2019) (yellow squares). (b) Comparison between simulated and observed tsunami runup heights by Badan Geologi's report (blue), BMKG (green), Omira et al. (2019)

535 (red), and Widiyanto et al. (2019) (yellow), as well as the comparison index, $K$ and $\kappa$ values. $n$ stands for the total number of observations. The gray shading represents the error related to the over/underestimation, i.e., $+/$ - standard deviation $(\sim 2.1 \mathrm{~m})$. 
(a)

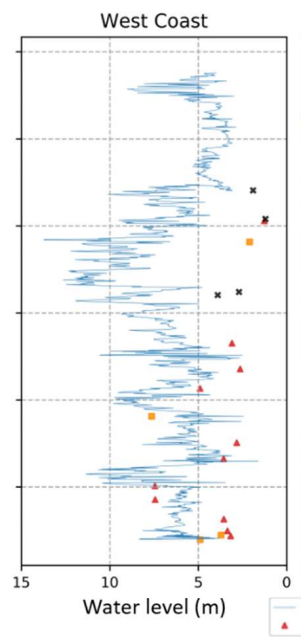

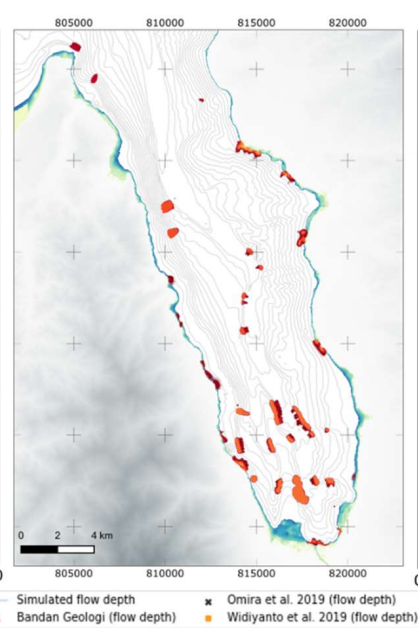
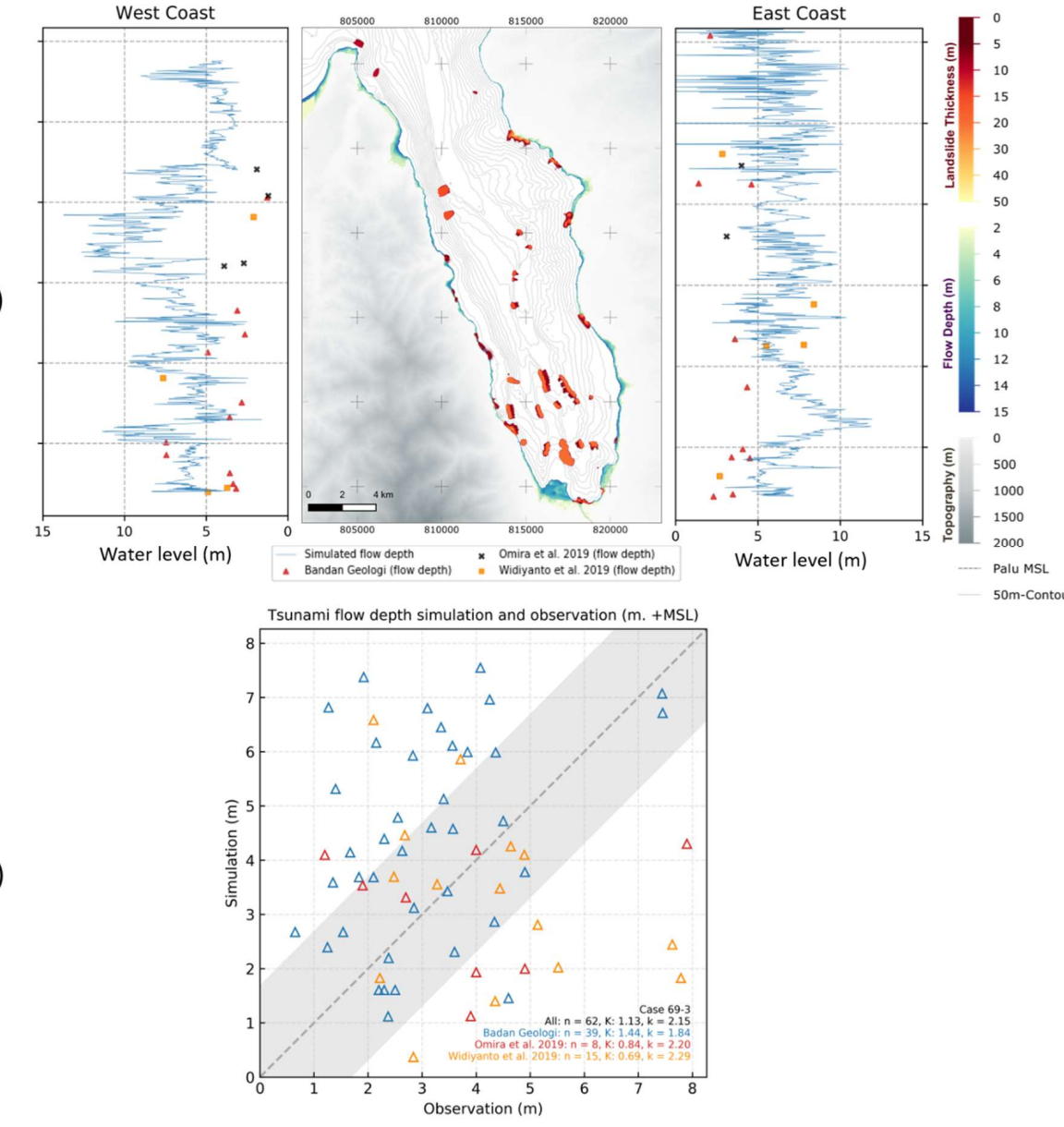

(b)

Figure 8 Simulated tsunami inundation depth (flow depth) with the modeled submarine landslides and observed submarine landslides from previous studies. (a) Calculated maximum flow depth (center) with the maximum calculated flow depth (blue line) at the shoreline of the (0) (2019) (crosses), and Widiyanto et al. (2019) (yellow squares). (b) Comparison between simulated and observed tsunami inundation depths by Badan Geologi's report (blue), Omira et al. (2019) (red), and Widiyanto et al. (2019) (yellow), as well as the comparison index, $K$ and $\kappa \square$ values. $n$ stands for the total number of observations. The gray shading represents the error related to the over/underestimation, i.e., $+/-$ standard deviation $(\sim 1.8 \mathrm{~m})$. 
(a)

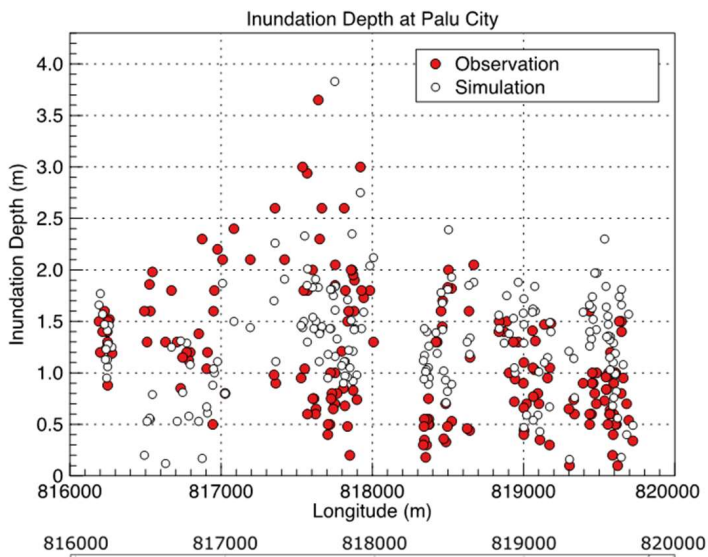

(b)

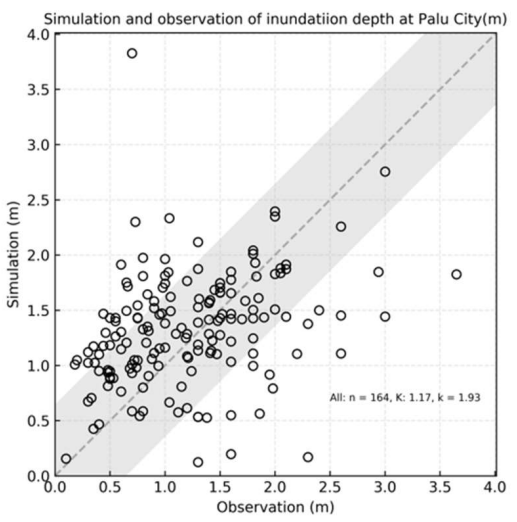

(c)

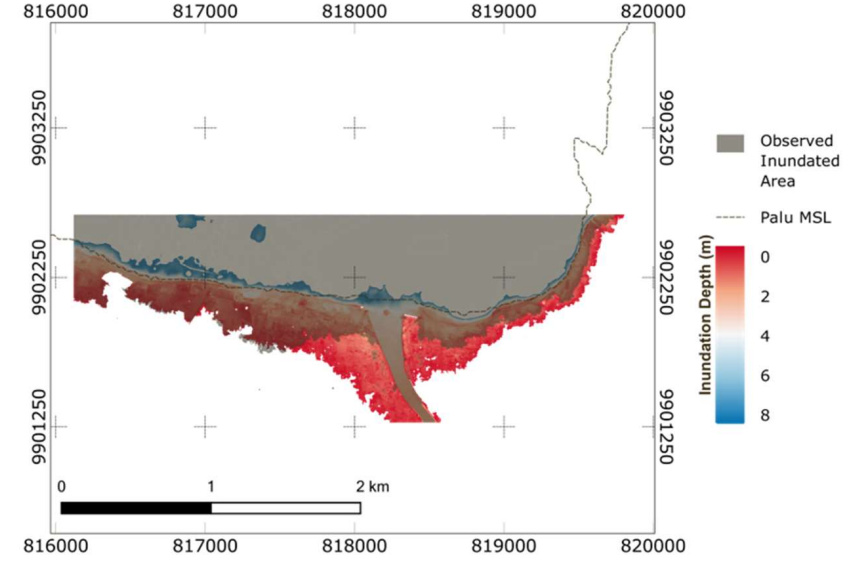

Figure 9 Tsunami inundation depths and the area around Palu city. (a) Simulated inundation depths and observation depths by Paulik et al. (2019) plotted over longitude. (b) Comparison between the simulated and observed tsunami inundation, as well as the comparison index, $K$ and $\kappa \sqcap$ values. $n$ stands for the total number of observations. (c) Simulated tsunami inundation area (in color) and the observed inundation area retrieved from Gusman et al. (2019) (in grayscale).

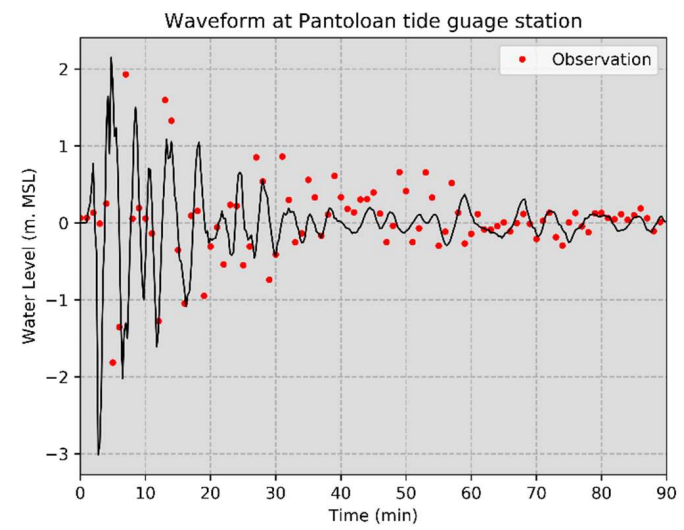


Figure 10 Time series of sea level at the Pantoloan tide gauge with detided sea level data. The black line represents the simulated waveform, and the red dot represents the sea level record at the Pantoloan tidal gauge.
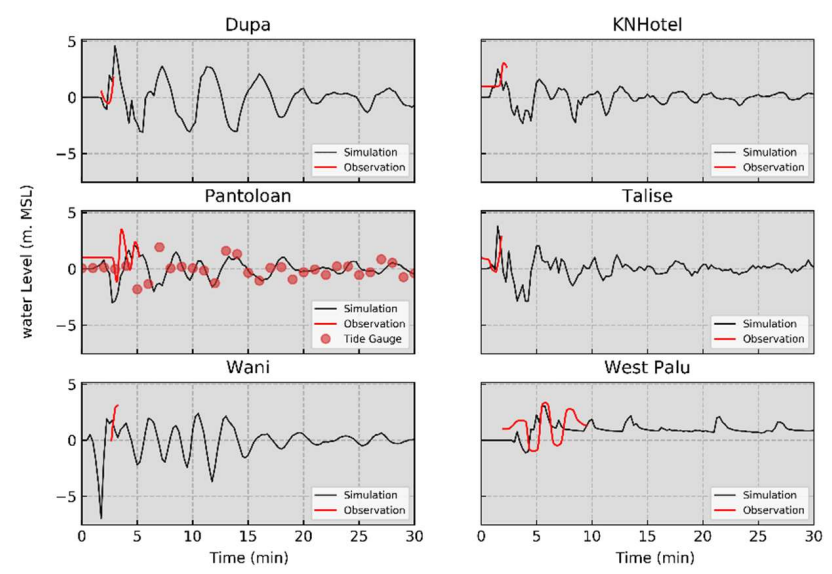

Figure 11 Time series of sea level for the 2018 Palu tsunami at 6 locations: Dupa, the KN Hotel, Pantoloan, Talise, Wani and West Palu. The 555 black line represents the simulated waveform, and the red line represents the video-inferred waveform retrieved from Carvajal et al. (2019). The simulated and observed waveforms are detided and adjusted to the same model's terrain datum. The location of each CCTV is shown in Fig. 6 . 